\title{
28 Research Soure \\ Evaluation of The Effects of Vitamin C on Epithelialization of Burn Wounds
}

\author{
Mohammd Haddadi \\ Islamic Azad University of Tabas
}

Elaheh Jaghouri

Sabzevar University of Medical Sciences

Davood Robat Sarpooshi

Sabzevar University of Medical Sciences

\section{Fateme Ghobadi}

Sabzevar University of Medical Sciences

Hamid Robat Sarpooshi ( $\sim$ Hamid.Robatsarpooshi@protonmail.com )

\section{Research note}

Keywords: vitamin C, healing, epithelization, burn, wound

Posted Date: June 24th, 2020

DOI: https://doi.org/10.21203/rs.3.rs-28024/v1

License: (c) (i) This work is licensed under a Creative Commons Attribution 4.0 International License.

Read Full License 


\section{Abstract}

Objectives: The purpose of the present study is to determine the effect of topical vitamin $\mathrm{C}$ on second degree burn wounds restoration. This was a clinical trial. The sample size was determined as 30 . The participants were selected from the patients suffering from second degree burns who visited the Burn Center of Vaseei Hospital in Sabzevar. Both intervention and control groups targeted one patient.

Dressing was changed in a daily manner after cleansing. Topical vitamin $\mathrm{C}$ solution was administered on the wounds. The Bates-Jensen Wound Assessment Tool was used to evaluate burn wound parameters in the $1^{\text {st }}, 3^{\text {rd }}, 7^{\text {th }}$ and $14^{\text {th }}$ day of treatment. Data analysis was performed using SPSS v. 16 and "repeated measures ANOVA.

Results: The average age of participants was $43.33 \pm 11.9$ years and $60 \%$ of the participants were males and $40 \%$ of them were females. The results of repeated measures ANOVA showed a statistically significant difference in mean scores of wound between the two treatments $(P=0.047)$, wound healing significantly differed in the two groups and topical vitamin $\mathrm{C}$ solution had a significant effect on acceleration of wound Epithelialization. According to the results of this study, administration of topical vitamin $\mathrm{C}$ is recommended for epithetlialization of second degree burns.

\section{IRCT: IRCT2015101224487N1}

\section{Introduction}

Burn is one of the major health problems around the world, especially in developing countries. Extensive burn injuries are not only life-threatening, but also have serious physical, psychological and economic effects on the patients, their families and society. Burn lesions are the third leading cause of unintentional injury deaths at all age groups and the second cause of trauma in children younger than 4 years of age. Approximately, two million people are given medical services for treatment of burn injuries every year in the United States [1]. According to relevant statistics in Iran, eight people with an average age of 35.7 die because of burning. Burn mortality rates in Iran is almost 3 times higher than Eastern Mediterranean countries and 2 times higher than global rate. Burn injuries lead to depression of immune potential, which may result in secondary infections [2.3]. A number of 152 people visited the Burn Center in Vaseei Hospital in Sabzevar in 2013. This figure increased to 190 people from the beginning of 2014 to the end of December 2014, which indicates an increase in the number of hospital refferals and burn statistics in Sabzevar.

Wounds are defined as a disruption of the normal structure and function of skin and underlying soft tissue. It is vital to maintain skin integrity, protect it against dehydration and bleeding, and prevent penetration of microorganisms into the skin. Skin wounds are caused by various physical, chemical and biological factors and are divided into chronic and acute wounds according to type and duration of repair [4]. 
Nutritional deficiencies can have adverse effects on wound and trauma injury healing. In this regard, researchers who study tissue repair dynamics have shown that several nutritional factors (e.g. vitamins, minerals and proteins) are effective in would healing and repairing [5].

Since tissues at the burned site are dead and block blood supply, white blood cells (WBC), antibodies and antibiotics cannot pass through bloodstream. This provides a suitable situation for growth of microorganisms. Therefore, topical antibiotics should be used to control infection at burned sites. Topical treatment helps to cleanse and close and open and dirty wound. Three common topical antibiotics used to heal burns are silver sulfadiazine, silver nitrate and Mafenide acetate. Silver with bactericidal and bacteriostatic activities has been used as an efficacious therapeutic agent for healing burn injuries over 50 years [6].

Epithelial tissue is an important and vital barrier to external factors. Damage to such barrier can lead to loss of water and electrolytes as well as metabolic disturbances. Epithelial tissue has a great capacity for repair and restoration. This capability is dependent on presence of epidermal stem cells in the basal layer and interfollicular epidermis. However, these cells are slow-cycling and have longer cell cycle time than delay tissue repair. On the other hand, time is an important factor in extensive burns [7].

Vitamin $\mathrm{C}$ is a water-soluble micronutrient required for various biological functions and is essential for wound healing and resistance to infection. It is also a potent antioxidant effective in maintaining vascular integrity and tone [8.3].

Vitamin $C$ infusion appears to be a useful in resuscitation of burn patients and minimizes fluid requirement. Oral Vitamin $C$ is administered for burn patients younger than 13 years old (250$500 \mathrm{mg} /$ day) and older than 13 years old ( $\leq 1000 \mathrm{mg} /$ day) [9]. Topical vitamin C reduces inflammatory reactions [10].

Some studies on pigs have shown an increase in vitamin C levels in the skin by administration of $10 \%$ vitamin $\mathrm{C}$ solution [11]. It is also acknowledged that different materials such as kiwi and jujube are effective in burn wound healing since they content high levels of vitamin $C$ (12.2). Various studies have acknowledged the effects of fatty acids and antioxidants (e.g. vitamin C) in accelerating wound healing [12].

Silver sulfadiazine dressing may cause false scar since the dressing adheres firmly to the wound surface, has toxic effects on keratinocyte repair, and delays wound healing [13].

Many patients in burn community have started using more high-dose vitamin $\mathrm{C}$ during complicated burn resuscitations[14]. The identification of the mechanisms regulating gene expression of oxidative stress markers, in the presence or absence of vitamin C, is important to understand the processes that influence the recovery of burn patients [3]. High-dose vitamin C therapy was associated with reduced in-hospital mortality in patients with severe burns under a minimum threshold of $10 \mathrm{~g}$ within the first 2 days of admission [15]. 
Since a large body of evidence confirms the effects of oral vitamin C on wound healing process and the effects of topical use of fruits containing vitamin $C$ on burn wounds, the present study aimed to evaluate the effects of topical vitamin $\mathrm{C}$ solution on burn wound in second degree burn patients.

\section{Materials And Methods}

In this study, patients' wounds were divided randomize in two groups of intervention and control. The participants were explained how to complete the consent form in case of their consent to participate in the study. Prior to the study, the patients' wounds were evaluated based on the Bates-Jensen Wound Assessment Tool by an observer physician. In the control group, routine wound cleansing and debridement were performed with water and normal saline. The wound was dried with sterilized gas and dressed with $1 \%$ sulfadiazine ointment with $1.5 \mathrm{~mm}$ thickness using sterile gloves. In the intervention group, routine cleansing and debridement were performed with water and normal saline. The wound was dried with sterilized gas and dressed with $10 \%$ vitamin $C$ solution. Vials containing $5 \mathrm{cc}$ vitamin $\mathrm{C}$ were used and sterile swabs were used to administer vitamin $C$ on the wound surface (maximum area of $225 \mathrm{~cm}$ was selected for each vial). Then, the wound was dressed with $1 \%$ silver sulfadiazine ointment with $1.5 \mathrm{~mm}$ thickness using sterile gloves. Finally, the burned site was dressed with Vaseline gas and dry gas.

Maximum surface of the organ compared with the identical organ or the section of an organ compared with another section of that organ was equal to $20 \%$ and minimum burned site at long surfaces was $6 \%$.

The depth of burned site was compared. Wound healing rates were compared on $1^{\text {st }}, 3^{\text {rd }}, 7^{\text {th }}$ and $14^{\text {th }}$ day of treatment using a checklist administered by an observer physician.

\section{Instrument}

Research instruments were demographic questionnaire, Bates-Jensen Wound Assessment Tool and a measuring tape. The wound assessment tool contained 15 items. Burned site and shape were not categorized but the other 13 items were scored based on a five-point Likert scale. Range of scores was between one and five. The lowest score (1) indicates the best healing rate and the highest score (6) indicates the worst healing rate.

The Bates-Jensen Wound Assessment Tool assesses wound size, depth, edges, undermining, necrotic tissue type, amount of necrotic, granulation and epithelialization tissue, exudate type and amount, surrounding skin color, edema, and induration. Wound healing process was evaluated according to obtained scores.

Scientific credibility of the Bates-Jensen Wound Assessment Tool was reviewed and confirmed by Harris et al. in 2010 [16]. Malek Hosseini et al. carried out a study in Arrack in 2010 and 2011 in order to determine scientific validity of the instrument in Iran and measured content validity of the instrument [13]. Content validity index was calculated as $89 \%$ in the former study. 
Malek Hosseini et al. determined scientific reliability of the instrument by studying 10 burn patients. The participants were observed separately by the researcher and his trained colleague as the subjects completed the Bates-Jensen Wound Assessment Tool. The correlation coefficient was calculated. The Hosseinis study measured reliability of the instrument and the Kappa coefficient for each item and confirmed reliability of the instrument.

To determine scientific credibility of the research instrument, 10 patients were selected and their wounds were separately examined by the physician and the researcher. The agreement coefficient was obtained as $95 \%$.

\section{Statistical Analysis}

The collected data was encoded and entered in the software. The data was monitored and accuracy of saved data was confirmed. Data analysis was performed using SPSS v.16. Repeated measures ANOVA were used for data analysis.

\section{Ethics}

This study was approved by the Graduate Council of Sabzevar Collage of Nursing and Midwifery with the ethics code of IR.MEDSAB.REC.1394.60 and Irct registration number of IRCT2015101224487N1. The researcher was given an introduction letter presented to the authorities of Vaseei Hospital and the Burn Center.

\section{Results}

Repeated measures ANOVA was used in order to determine the effects of the topical vitamin C solution on epithelization of second degree burn wounds.

The results of repeated measures ANOVA showed that mean score of epithelialization between two treatments was statistically significant $(P=0.047)$. The healing rate significantly differed in the two groups and topical vitamin $\mathrm{C}$ had a significant effect on epithelialization of the wound (Table 1).

Regarding the intra group effects, the effect of time on mean score of epithelialization was statistically significant and mean score of epithelialization was significantly different on the $1 \mathrm{st}$, 3rd, 7th and 14th day of treatment $(P=0.000, F=141.324)$. Different days or time was effective in tissue granulation.

Interactive effect of dressing type and time was studied. The results of repeated measures ANOVA showed that epithelization score was significant in the two intervention and control groups on the 1st, 3rd, 7th and 14th day of treatment $(P=0.005, F=7.534)$. Epithelization score was statistically significant in different days in both groups.

Partial Eta Squared explained changes in wound healing in this study. This index explained $70.9 \%$ of time, $9 \%$ of interactive effect of dressing type and time and $6.7 \%$ of vitamin $\mathrm{C}$ of changes in wound 
healing.

Table 1

Comparison of mean score of epithelialization in intervention and control groups after dressing

\begin{tabular}{|c|c|c|c|c|c|}
\hline \multirow{2}{*}{$\begin{array}{l}\text { Group } \\
\text { Statistics }\end{array}$} & & \multicolumn{2}{|c|}{ Intervention } & \multicolumn{2}{|c|}{ Control } \\
\hline & & Mean & $\begin{array}{l}\text { Standard } \\
\text { deviation }\end{array}$ & Mean & $\begin{array}{l}\text { Standard } \\
\text { deviation }\end{array}$ \\
\hline \multirow[t]{4}{*}{ Epithelization score } & 1st day & 5.00 & 0.00 & 5.00 & 0.00 \\
\hline & 3rd day & 4.76 & 0.67 & 4.76 & 0.62 \\
\hline & 7th day & 3.70 & 1.11 & 4.23 & 1.00 \\
\hline & 14th day & 2.40 & 1.10 & 3.20 & 1.18 \\
\hline \multicolumn{2}{|c|}{ Effect of time (intragroup effect) } & $\begin{array}{l}F= \\
141.324\end{array}$ & $\mathrm{df}=1.936$ & $\begin{array}{l}P< \\
0.001\end{array}$ & \\
\hline \multicolumn{2}{|c|}{$\begin{array}{l}\text { Interactive effect dressing and } \\
\text { time }\end{array}$} & $F=4.133$ & $\mathrm{df}=1$ & $\begin{array}{l}P= \\
0.047\end{array}$ & \\
\hline
\end{tabular}

\section{Bonferroni test}

There was a significant difference in mean score of epithelialization in different days in pairs comparison. The difference between the scores was significant except between the first and the third days. The mean score of epithelization increased from the first day to the fourteen day. Burn wound was healed during studied time (Table 2). 
Table 2

Two-by-two comparison of mean scores of epithelization in studied days

\begin{tabular}{|llll|}
\hline $\begin{array}{l}\text { Two-by-two comparison in studied } \\
\text { days }\end{array}$ & $\begin{array}{l}\text { Difference between } \\
\text { means }\end{array}$ & $\begin{array}{l}\text { Standard } \\
\text { error }\end{array}$ & $\begin{array}{l}\text { Significance } \\
\text { level }\end{array}$ \\
\hline 1 & 0.233 & 0.0840 & 0.080 \\
\hline 7 & 1.033 & 0.1370 & $<0.001$ \\
\hline 3 & 2.200 & 0.1480 & $<0.001$ \\
\hline 14 & -0.233 & 0.0840 & 0.008 \\
\hline 7 & 0.800 & 0.0980 & $<0.001$ \\
\hline 1 & 1.967 & 0.1340 & $<0.001$ \\
\hline 14 & -1.033 & 0.1370 & $<0.001$ \\
\hline 3 & -0.800 & 0.0980 & $<0.001$ \\
\hline 14 & 1.167 & 0.0920 & $<0.001$ \\
\hline 1 & -2.200 & 0.1480 & $<0.001$ \\
\hline 3 & -1.967 & 0.1340 & $<0.001$ \\
\hline 7 & -1.167 & 0.0920 & $<0.001$ \\
\hline
\end{tabular}

Figure 1 was drawn to determine the effects of topical vitamin $C$ solution on epithelization of seconddegree burn wounds. Mean score of epithelization in both intervention and control groups was identical on the $1^{\text {st }}$ and 3rd days of treatment but the slope of the graph increased on the $3^{\text {rd }}$ day in the intervention group and peaked on the $14^{\text {th }}$ day. This shows that topical vitamin $\mathrm{C}$ solution had a greater effect on epithelization of the wound in the intervention group compared to control.

\section{Discussion}

The study aimed to determine the effects of topical vitamin $\mathrm{C}$ solution on epithelium of second degree burn wounds. The rate of epithelization was significantly different in the two groups, vitamin $\mathrm{C}$ had a significant effect on epithelialization, and time was also effective in wound healing. Mean epithelization score increased on the third day and decreased from 3.20 in control to 2.40 in the intervention group on the 14th day. Abbaspour and Khaksari studied the effect of kiwi on epithelialization of burned scars in mice. The results of the former study were consistent with the results of this study [2].

Lima et al. studied the effect of Vitamin C in healing skin scars in mice. They detected less symptoms of inflammation, more granulation tissues, lower number of macrophage and new vessels in the intervention group compared to control [17]. Wiesner and Gold studied treatment of bedsore and chronic wounds with topical vitamin $\mathrm{C}$ and showed that vitamin $\mathrm{C}$ solution helps formation of new tissues and abundant 
granulation tissues in patients with bedsore [18]. These results are consistent with the results of this study.

\section{Conclusion}

This study showed that topical vitamin C solution can accelerate epithelialization and repairing of burn wounds.

\section{Limitations}

Intervention and control groups were restricted to a certain patient and investigations were carried out on 30 samples collected from this patient. It is recommended to collect more samples with identical conditions in future studies. Although the effect of many intervening variable were eliminated by combining intervention and control, this combination is a significant advantage of this study.

\section{Abbreviations}

ANOVA: Analysis of variance

SPSS: Statistical Package for the Social Sciences

\section{Declarations}

\section{Availability of data and materials}

Data were available upon request.

\section{Acknowledgement}

We appreciate the helps of authorities of Sabzevar College of Nursing and Midwifery. We are also grateful to nurses and good personnel of the Burn Center of Vasei Hospital in Sabzevar, the patients and their families who helped us to carry out this project.

\section{Funding}

There is no funding for present study.

\section{Authors' Contributions}

Study design and concept: MH and HRS, Ligature review: EH and DRS; performing the study: MH, HRS, and EJ; drafting: DRS. All author approved the study.

\section{Ethics approval and consent to participate}


This study was approved by the Graduate Council of Sabzevar College of Nursing and Midwifery with the ethics code of IR.MEDSAB.REC.1394.60. Patients signed a written consent.

\section{Consent for publication}

Not applicable.

\section{Competing interests}

The authors declare that they have no competing interests.

\section{References}

1. Darvishpour A, Lotfi M, Salehi F, Aghazadeh A, Hasani A, Ali N. Comparing Dressing With Silver Sulfadiazine and Nitrofurazone to the Pediatrice Ward in Tabriz. J of Guilan Univer of Med Science. 2006;15(60):42-6.

2. Abbaspour $H$, Khaksari M. Topical effectiveness of Kiwifruit on burn wound healing in male rats. 2013.

3. Bonucci J, Gragnani A, Trincado MM, Vincentin V, Correa SAA,Ferreira LM. The role of vitamin C in the gene expression of oxidative stress markers in fibroblasts from burn patients. Acta Cir Bras. 2018;33(8):703-12.

4. Jaffary F, Nilforoushzadeh MA, Sharifian H, Mollabashi Z. Wound healing in animal models. Tehran University Medical Journal TUMS Publications. 2017;75(7):471-9.

5. Mahdavi-Shahri N, Baharara J, Tavassoli A, Rasti H, Shahabipour F, Saghiri N. Effect of All-Trans Retinoic Acid on Epithelialization of Blastema Tissue in vitro. Journal of Rafsanjan University of Medical Sciences. 2012;11(5):471-80.

6. Smeltzer SC, Bare BG. Brunner \& Suddarth's textbook of medical-surgical nursing: JB Lippincott Philadelphia; 1992.

7. Safari M, Ghahari L, Khoushvaghti A, Nasiri E. Ulcert Repair by Spray of Epithelial Stem Cells. 2008.

8. Abgoon M. Iranian generic drugs. 3rd ed. Tehran: Noore Danesh; 2000.

9. Herndon DN. Total burn care: Elsevier Health Sciences; 2007.

10. Singh $P$, Singh $P$, Talhar S, Sontakke B, Bokariya $P$, Tarnekar A. Role of topical ascorbic acid in management of refractory corneal ulcer. IOSR J Pharm. 2012;2(6):1-4.

11. Draelos ZD. Nutrition and enhancing youthful-appearing skin. Clin Dermatol. 2010;28(4):400-8. http://dx.doi.org/10.1016/j.clindermatol.2010.03.019www.ncbi.nlm.nih.gov/pubmed/20620756.

12. Ashrafi K, Esmaeli E, Shahinfard N, Ansari R, Parvin N, Namjoo A. The effect of hydroalcoholic extracts of Zizipus vulgaris L. on burn healing. J Shahrekord Univ Med Sci. 2011;12(4):78-82. Persian. 
13. Ghaffarzadegan R, Alizadeh SA, Ghaffarzadegan R, Haji Agaei R, Ahmadlou M. Effect of aloe vera gel, compared to $1 \%$ silver sulfadiazine cream on second-degree burn wound healing. Complementary Medicine Journal of faculty of Nursing Midwifery. 2013;3(1):418-28.

14. Buehner M, Pamplin J, Studer L, Hughes RL, King BT, Graybill JC, et al. Oxalate Nephropathy After Continuous Infusion of High-Dose Vitamin $\mathrm{C}$ as an Adjunct to Burn Resuscitation. Journal of Burn care \& Research Volume 37, Number 4; e379.

15. Nakajima M, Kojiro M, Aso S, Matsui H, Fushimi K, Kaita Y, et al. Effect of high-dose vitamin $C$ therapy on severe burn patients: a nationwide cohort study. Crit Care. 2019;23:407.

16. Harris C, Bates-Jensen B, Parslow N, Raizman R, Singh M, Ketchen R. Bates-Jensen wound assessment tool: pictorial guide validation project. J Wound Ostomy Continence Nurs2010;37(3):253-9.

http://dx.doi.org/10.1097/WON.0b013e3181d73aabwww.ncbi.nlm.nih.gov/pubmed/20386331.

17. Lima C, Pereira A, Silva J, Oliveira L, Resck M, Grechi C, et al. Ascorbic acid for the healing of skin wounds in rats. Brazilian Journal of Biology. 2009;69(4):1195-201.

18. Mester A. Treatment of bedsores and chronic ulcers with topical ascorbic acid. Lancet. 1961;1:3434.

\section{Figures}

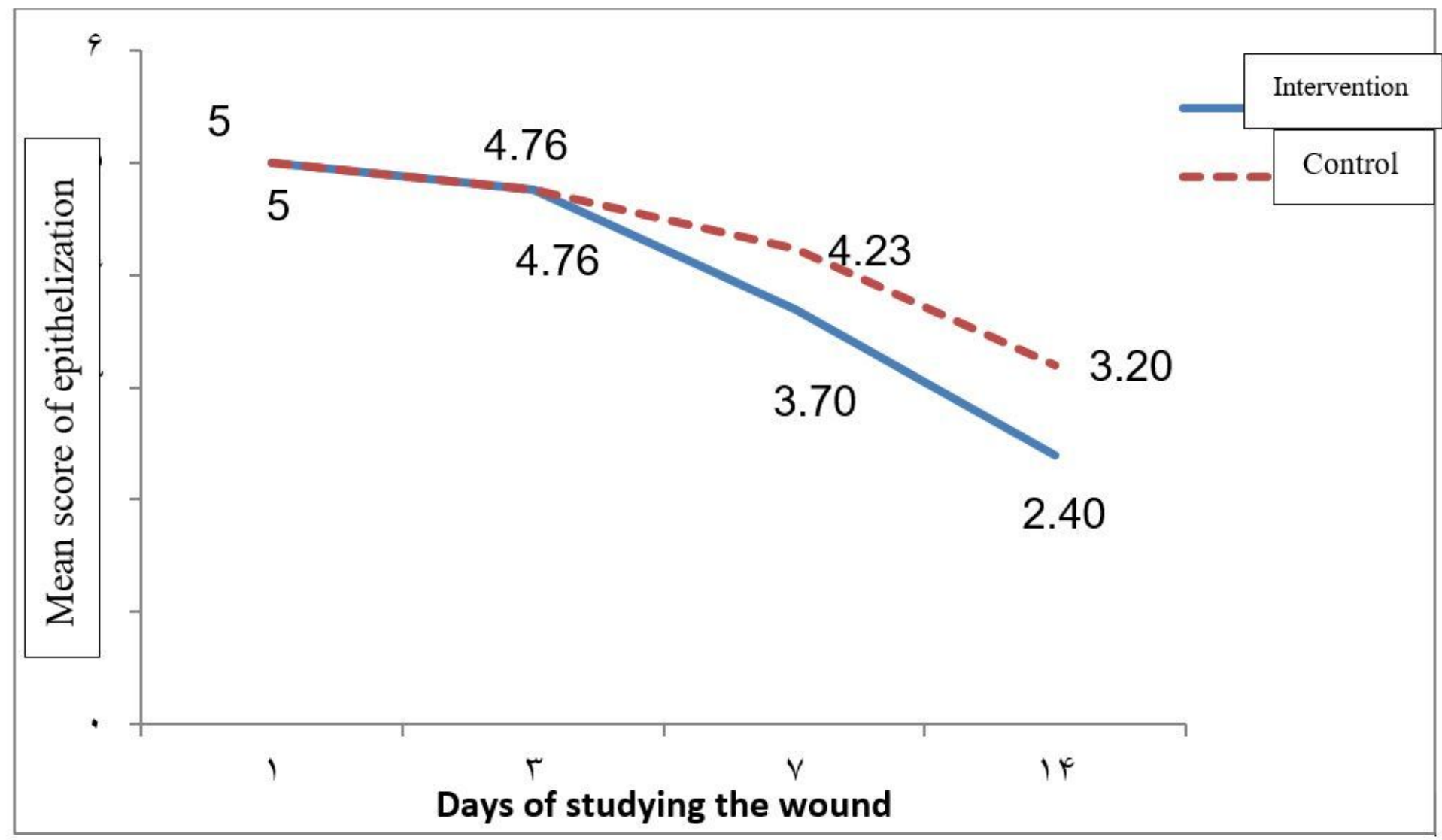


Comparison of mean scores of epithelialization

\section{Supplementary Files}

This is a list of supplementary files associated with this preprint. Click to download.

- CONSORT2010Checklist.doc 